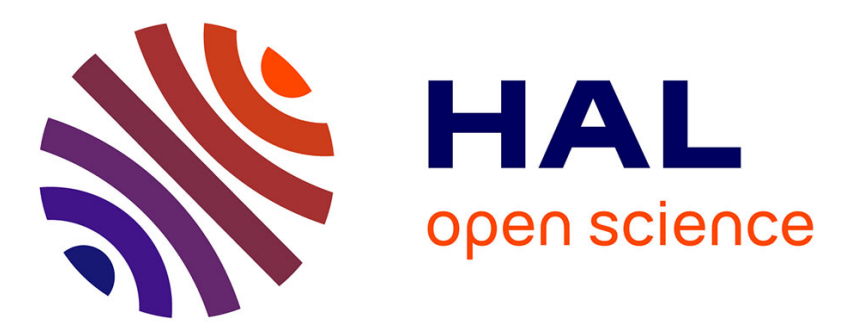

\title{
Local Organic Food for Local People? Organic Marketing Strategies in England and Wales
}

Matt Lobley, Allan Butler, Michael Winter

\section{To cite this version:}

Matt Lobley, Allan Butler, Michael Winter. Local Organic Food for Local People? Organic Marketing Strategies in England and Wales. Regional Studies, 2011, pp.1. 10.1080/00343404.2010.546780 . hal00676994

\section{HAL Id: hal-00676994 \\ https://hal.science/hal-00676994}

Submitted on 7 Mar 2012

HAL is a multi-disciplinary open access archive for the deposit and dissemination of scientific research documents, whether they are published or not. The documents may come from teaching and research institutions in France or abroad, or from public or private research centers.
L'archive ouverte pluridisciplinaire HAL, est destinée au dépôt et à la diffusion de documents scientifiques de niveau recherche, publiés ou non, émanant des établissements d'enseignement et de recherche français ou étrangers, des laboratoires publics ou privés. 


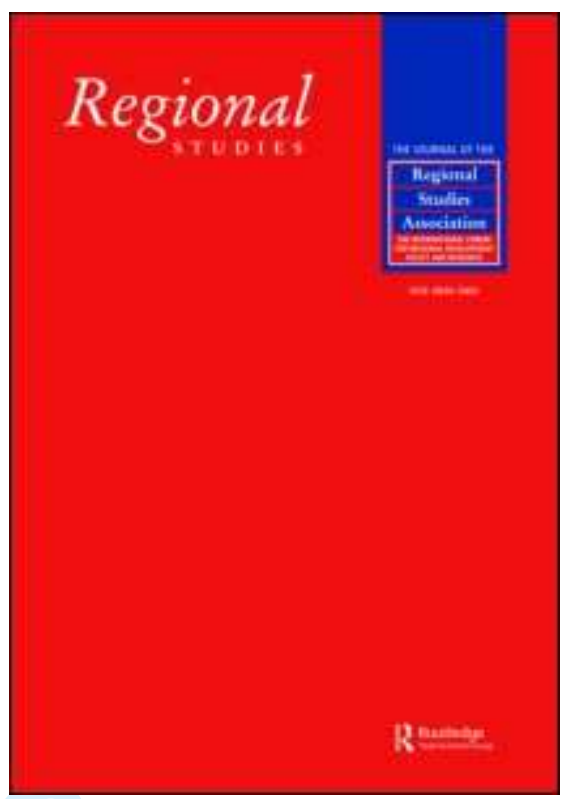

\section{Local Organic Food for Local People? Organic Marketing Strategies in England and Wales}

\begin{tabular}{|r|l|}
\hline Journal: & Regional Studies \\
\hline Manuscript ID: & CRES-2010-0059.R2 \\
\hline Manuscript Type: & Main Section \\
\hline JEL codes: & $\begin{array}{l}\text { L1 - Market Structure, Firm Strategy, and Market Performance < L - } \\
\text { Industrial Organization, O13 - Agriculture; Natural Resources; } \\
\text { Energy; Environment; Primary Products < O1 - Economic } \\
\text { and Growth, Q12 - Micro Analysis of Farm Firms, Farm Households, } \\
\text { and Farm Input Markets < Q1 - Agriculture < Q - Agricultural and } \\
\text { Natural Resource Economics, Q13 - Agricultural Markets and } \\
\text { Marketing|Cooperatives|Agribusiness < Q1 - Agriculture }<\text { Q - } \\
\text { Agricultural and Natural Resource Economics }\end{array}$ \\
\hline \hline Keywords: & $\begin{array}{l}\text { Herfindahl-Hirschman Index, Local food, Marketing concentration, } \\
\text { Market orientation, Organic food, England and Wales }\end{array}$ \\
\hline \hline
\end{tabular}

\section{SCHOLARONE" Manuscripts}


Local Organic Food for Local People? Organic Marketing Strategies in England and Wales

M. Lobley ${ }^{\mathrm{a}}$; A. Butler ${ }^{\mathrm{a}}$; M. Winter ${ }^{\mathrm{a}}$

(Received February 2010: in revised form November 2010)

\author{
${ }^{a}$ Centre for Rural Policy Research, Department of Politics, University of Exeter, \\ Amory Building, Rennes Drive, Exeter, UK. EX4 4RJ. +44(0)1392 264539 \\ emails: m.lobley@exeter.ac.uk; Allan.J.Butler@exeter.ac.uk; \\ D.M.Winter@exeter.ac.uk
}




\begin{abstract}
Organic agriculture has a totemic role in debates about farming. Domestic organic production is thought to play a role in relocalised food networks. However, little is known about the market orientation of organic producers in England and Wales. Drawing on a mixed methods approach this paper characterises national, regional and local markets for organic food from a supply perspective. It identifies local, regional and national market orientation and considers the concentration of marketing channels using the Herfindahl-Hirschman Index. The analysis demonstrates the heterogeneity of the sector and an uneven geography of organic marketing in England and Wales.
\end{abstract}

\author{
Keywords \\ Herfindahl-Hirschman Index; Local food; Marketing concentration; Market \\ orientation; Organic food; England and Wales
}

JEL codes: Q1; Q12; Q13 
Introduction

The totemic importance of the organic movement in both policy and market terms has spawned a large and diverse literature on organic farming, with evidence suggesting that organic farming can provide a wide range of benefits, including positive employment impacts, improved environmental benefits and support for local and regional economies (e.g. GABRIEL et al., 2009; MICHÈLE and MICHAEL, 2009; RUNDLOF, 2008; LOBLEY et al., 2005, 2009; MORISON et al., 2005; MIDMORE and LAMPKIN, 1994; PADEL and LAMPKIN, 1994; HIRD, 1997). Within Europe, government support for organic farming developed in the late 1980s based on a recognition of the wider environmental benefits of organic agriculture (STOLZE and LAMPKIN, 2009). Since then the area of land under organic management has grown rapidly. From less than 7,000 farmers managing 105,000ha of land in 1985 (STOLZE and LAMPKIN, 2009), by 2007 there were some 7.2 million hectares of organically farmed land in the EU, managed by over 180,000 organic farmers, serving a market estimated to be worth 16 billion Euros (WILLER and KLICHER, 2009). Within the EU the size of the retail market for organic food in the UK is second only to that in Germany (WILLER and KLICHER, 2009).

After a period of rapid growth, the area of organically farmed land has remained relatively constant in recent years. For example, the total area of registered organic land in the UK in 2007 was 682,196 ha compared to 694,979 ha in 2003 . Since then there has been a slight increase in conversions so that the total area of organic land in 2008 was 743,516 ${ }^{1}$ (DEPARTMENT OF ENVIRONMENT, FOOD AND RURAL AFFAIRS, 2009a). On the other hand, until very recently, retail sales have grown by approximately $27 \%$ per annum over the last decade (SOIL ASSOCIATION, 2007), 
leading to an estimated annual market value of $£ 1.9$ billion in 2006 and over $£ 2.1 \mathrm{~b}$ in 2008, although much of this latest increase is likely to reflect rising food prices rather than an increase in the volume of sales (SOIL ASSOCIATION, 2009). Despite the rapid growth of the organic market, constraints in the supply chain, in particular limited growth in the area farmed, mean that the sourcing of organic produce is frequently met by imported food (SOIL ASSOCIATION, 2001), although this varies considerably by sector.

Nevertheless, domestic production remains important, not least because of its assumed potential to contribute to 'alternative' and relocalised food networks. There is a frequently perceived link between organic farming and short supply chains serving local markets (DARNHOFER, 2005). As CLARKE et al. (2008 p. 220) comment "the supposedly localised nature of organic food is claimed to have reduced the food miles inherent in conventional food commodity chains and produced a trusting (re)connection between the anxious consumer and the responsive producer". However, they challenge the "supposedly localised nature of organic food" (CLARKE et al., 2008 p. 220) and call for more critical and reflexive accounts of organic food networks. Indeed, as SMITH and MARSDEN (2004) argue, it is important not to treat organic farming as a single homogeneous category but to examine particular supply chain dynamics in particular organic sectors in different regional, local and national settings. For instance, in countries with a large organic sector, such as Austria, saturation of the local market means that organic producers must seek other markets for their outputs (DARNHOFER, 2005). On the other hand, it has been suggested that in Greece the existing market structure facilitates the direct marketing of organic produce (DANTSIS et al., 2009) and that Mediterranean and 
southern European countries are more often associated with local food cultures and the persistence of small-scale farming, never having fully completed the transition to globalised forms of food production and distribution (FONTE, 2008).

In the UK, although Soil Association ${ }^{2}$ data point to a small but growing alternative retail sector in the organic market (SOIL ASSOCIATION, 2009), relatively little is known about the market orientation of domestic organic producers, the marketing routes they employ and how these vary geographically and by sector. Indeed, according to TOMLINSON (2008 p.135), "the UK organic sector is somewhat elusive". The overall aim of this paper therefore is to take a fresh look at organic production in England and Wales in order to explore the market channels employed by organic farmers, the degree of marketing concentration in the domestic organic sector and to consider the market orientation of organic farmers and how this varies geographically and by sector. Without this more detailed knowledge of marketing, there is a danger that commentators will continue to readily conflate 'local' and 'organic' with often misleading and potentially exaggerated conclusions about the role that organic farming might play in local and regional rural development strategies. Consequently, the main objective is to establish the nature of organic producers' marketing strategies and in so doing to contribute to the debate regarding the supposed local nature of organic farming markets in England and Wales.

Organic farming markets

Despite a presumed close alliance between organic food and local food (LOBLEY et al., 2009; CLARKE et al., 2008) which has been explored sociologically in some studies (e.g. SEYFANG, 2007), few publications have explored the extent to which 
organic farming is integrated into the local economy (but see LOBLEY et al., 2009 and DARNHOFER, 2005) and as ILBERY et al (2010) point out, not one of the seminal works on marketing considers the marketing channels used by organic producers. Much of the interest in local organic food stems from concerns to reduce the environmental costs of food production and distribution, as well as a desire to reconnect farmers and consumers and help retain income generated by organic producers in the local economy (e.g. CRANBROOK, 2006; ILBERY and MAYE, 2005; PRETTY et al., 2005). However, as organic certification regimes tend to focus on the technical aspects of the farming system rather than broader social values (PADEL et al., 2009), certification alone does not necessarily lead to the sort of alternative, localised food systems often assumed to be part of organic agriculture (DARNHOFER et al., 2010). Consequently, in a case study of organic producers in Central Macedonia, DANTSIS et al. (2009 p.204) adopt a strongly normative position and argue that if organic producers are to contribute towards sustainability goals they "should select particular and local distribution channels ... so that so-called direct marketing is achieved". Despite research from several EU countries (e.g. DANTSIS et al., 2009; SEYFANG 2006; DARNHOFER, 2005) suggesting that organic supply chains may contribute to rural development by giving farmers greater control of their market and retaining a greater proportion of food spend in the local economy, recent evidence suggests that in England organic farmers are no more connected to their local economy than are non-organic farmers (LOBLEY et al., 2009).

This may be an indication of the so-called conventionalisation of organic farming and marketing, the process by which, over time, organic farming systems, structures and supply chains increasingly take on characteristics of the conventional system to which 
organics is so often seen to be in opposition to. Conventionalisation has been much debated both as a theoretical concept and observable empirical trend (e.g. DANTSIS et al., 2009; GUPTILL, 2009; LOCKIE and HALPIN, 2005; BEST, 2008; TOVEY, 1997; HALL and MOGYORODY, 2001), with mixed results. Most writers find that conventionalisation does not operate as strongly as in the Californian context where the concept was developed by GUTHMAN (2004). For instance, GUPTILL (2009, p.31) in upstate new York, found "moderate but highly contingent support" for the concept and suggested that while the drivers of conventionalisation are apparent the "hypothesised effects do not necessarily follow". In the former West Germany, BEST (2008) found "tendencies" towards conventionalisation but also sufficient variation as to question the utility of the concept. More recently, drawing on evidence from New Zealand, ROSIN and CAMPBELL (2009) have argued that by establishing a dualism between the 'ideal' and 'good' alternative and the 'bad' conventional, conventionalisation fails to recognise positive developments towards more sustainable forms of agriculture and fails to give credence to the diversity of 'organic'. Similarly, GUPTIL (2009) argues that "the tremendous diversity within the agro-food system means that 'organics' is hardly a more unitary term than 'farming"' (p.40).

Despite vigorous debate over the conventionalisation thesis and widespread academic interest in the organic movement, relatively little is known about UK organic markets, notwithstanding the regular organic market reports produced by the Soil Association. Unsurprisingly, the rapid expansion of the UK organic market has been slowed by the recession. Nevertheless, sales continued to grow, albeit at low levels, in 2008 with sales through multiples growing by $1.8 \%$ and sales through non-multiples growing by 1.4\%. Interestingly, sales through farmers' markets grew by $18.6 \%$ in 2008 . That said, 
farmers' markets account for only $1.1 \%$ of the UK organic market, compared to the 73.1\% share of the multiples (SOIL ASSOCIATION, 2009). Although it is possible to infer from such studies that most producers must supply the main multiples, either directly or indirectly, there is little evidence concerning which producers serve different markets, where they are located, the types of businesses they run, nor the determinants of any particular approach to the marketing of organic produce by organic farmers. One exception is provided by ILBERY et al. (2010) who draw in part on qualitative interviews with a small sub-sample of a much larger survey of organic farmers in England and Wales which forms the empirical basis of the current paper. Although confined to three 'core' organic areas of East and West Sussex, Ceredigion and Pembrokeshire, and Devon and Somerset, the paper by Ilbery and colleagues represents the first attempt to calculate indices of marketing concentration for organic farms in England and Wales. Their results point to a high degree of market concentration with some significant variations between their study areas, leading the authors to conclude that "the type of marketing channel used by organic farmers in the case study regions in England and Wales is clearly influenced by place" (p.971). Reflecting on the somewhat artificial dualism constructed by the conventionalisation theses, they also suggest that a "simple binary distinction between national/commodity markets and local/alternative chains is not always helpful" (p.967) as a number of producers often combine different local and national marketing channels. The rest of this paper considers the marketing strategies adopted by organic producers in England and Wales, exploring the reasons why particular strategies are adopted and the impact of these strategies on the farms and the producers themselves. The analysis is based on a large postal survey of organic farmers which is described in the next section. 
Methods and overview of the sample

A postal questionnaire was designed in order to collect a range of data on the production and marketing of organic food in England and Wales. A sample of 1,532 farms was drawn from a Defra database of organic farms stratified using Location Quotient (LQ) methodology. The LQ measures the relative concentration of a phenomenon (number of organic farms) in each County and Unitary Authority (CUA) by comparing that phenomenon with the total number of farms in the CUA (ILBERY et al. 1999, ILBERY and MAYE 2010). Following ILBERY et al. (1999), the LQ ratio is calculated using:

Number of organic farms in CUA ' $\mathrm{x}$ ' $\div$ Number of organic farms in England and Wales Number of farms in CUA ' $\mathrm{x}$ ' $\div$ Number of farms in England and Wales

An LQ ratio of 1.0 signifies that an area's share of organic farms is the same as the overall number of farms in that area. Areas with an LQ ratio over 1.0 have a greater relative spatial concentration. However, one weakness of the LQ ratio is its sensitivity to small numbers which can result in some of the smaller geographical units (metropolitan counties and unitary authorities) having to be treated with caution (ILBERY and MAYE 2010). Therefore, to ensure a representative stratified sample, the LQ methodology has been used to measure the relative distribution of organic farms within each Government Office region rather than at the CUA level. ${ }^{3}$ 
The survey (which took place in 2007) produced a total of 514 completed questionnaires, of which 475 were useable for subsequent analysis (a response rate of $32.7 \%$ ). In addition, a series of focus groups was convened in early 2009 in order to provide the opportunity for producers to discuss the results of the project and provide feedback on some of the key questions generated by the study. The locations for the focus groups were in the study areas of Sussex, in South East England, and southwest Wales. In practical terms, these areas contained relatively large number of participants who had indicated a willingness to take part in further aspects of the project.

Overview of the sample

The total area of organic farms in the survey was 84,168 ha, of which 62,260 ha were registered as organic with a further 7,708 ha in organic conversion. The registered organic land captured by the survey accounts for $21.3 \%$ of all organic land in England and Wales. The survey not only reflects a significant proportion of organic production in England and Wales, it also reflects the diversity of organic farming. For instance, the survey captured a wide range of farm sizes. The mean size of survey farms was 177 ha, of which 132 ha were registered organic ${ }^{4}$.

Farms in the sample operated a wide array of organic agricultural enterprises ranging from beef and sheep to venison and water buffalo. The two most common types of farm were beef and sheep (31.3\% of sample farms) and mixed farms $(25.8 \%$ of sample farms). The relatively large proportion of mixed farms reflects the nature of organic farming systems which tend to favour mixed farming. The low proportion of arable farms in the sample (just $4.5 \%$ ) can be explained in the same way: $38.0 \%$ of the 
sample reported operating a cereal enterprise but only $9.1 \%$ stated that this was their most important enterprise. The implication is that most farms with arable enterprises are growing their own feed so, although cereal production is widespread, few farms in the sample can be classified as arable.

The overall value of sales recorded by the farm survey was $£ 76$ million, of which $73.7 \%$ was directly associated with organic enterprises. The mean value of organic sales per farm was $£ 135,894$, although the median value was much lower at $£ 54,000$, suggesting that a few farms account for a disproportionate amount of organic sales. Indeed, $80 \%$ of all farms had organic sales below $£ 200,000$ and just $10 \%$ of farms in the survey accounted for over $50 \%$ of sales. Of these, one-third were dairy farms and a further $40.5 \%$ were mixed farms. The same 'top $10 \%$ ' of farms employed one-third of the workforce, although this increased to $49.9 \%$ when only full-time employees were considered. This concentration of production in the hands of a relatively small proportion of larger farms is a common feature of the non-organic sector and is one of the empirical trends which is often seen to indicate the 'conventionalisation' of the organic sector (LOCKIE and HALPIN, 2005). However, such concentration trends reveal little about market channels and resulting local economic impacts.

\section{Market channels for organic produce}

There are a number of approaches to describe and analyse the marketing behaviour of farmers. For instance, marketing cooperatives, contracts with processors, farm-tofarm sales and sales to wholesalers were the most frequently occurring market channels. Together, marketing cooperatives and contracts with processors accounted for $42.6 \%$ of all marketing channels recorded in the survey and account for $26.4 \%$ and 
$24.0 \%$ respectively of all sales by value. Farmers' own box schemes accounted for only $4.6 \%$ of all sales but all direct sales to the end consumer represent $10.1 \%$ of the value of all produce traded by farmers in the survey. The Soil Association's assessment of the 2008 UK organic market (SOIL ASSOCIATION, 2009) indicates an $11 \%$ market share by direct sales through box schemes, farmers' markets, farm shops and other home delivery and mail order market routes.

An alternative approach to understanding farmers' use of different marketing channels is to consider marketing concentration, as measured using the Herfindahl-Hirschman Index (HHI) ${ }^{5}$. The Hirschman-Herfindahl index (HERFINDAHL, 1950; HIRSCHMAN, 1964) is a useful measure of market structure that has support in economic theory and empirical studies (MILLAR, 1982) and is a commonly accepted measure of marketing concentration (LEE and BROWN, 1989; ILBERY et al., 2010). In many cases, the HHI is used to analyse the concentration of firms in a particular industry, captured by the formula:

$$
H H I=\sum_{i=1}^{N} S_{i}^{2}
$$

Equation (1)

where $\mathrm{S}$ is the market share of the $\mathrm{i}^{\text {th }}$ firm. Our approach follows the lead of ILBERY et al. (2010) who used HHI in a slightly different manner in order to examine the concentration of marketing channels of individual firms (farms). ILBERY et al. (2010) refer to it as the 'Index of marketing concentration' as it indicates the proportion of outputs sold through each marketing channel. Therefore, in Equation (1), $S$ refers to the squared proportion of organic produce sold through marketing channels of the farm rather than a firm's market share. 
The HHI score illustrates the concentration of marketing channels on farms where 1 equates to $100 \%$ of produce being marketed via a single route. For the whole sample, the $\mathrm{HHI}$ is relatively high at 0.75 (see Table 1). While some farms have a diverse set of marketing channels, $35.9 \%$ of farms record an HHI score of 1, indicating a focus on a single marketing channel. Analysis of the geography of market concentration reveals some interesting patterns (although these are not significant in a statistical sense). In all but in the North East region, the median HHI score is greater than the mean indicating that the mean is skewed towards farms that sell their produce through few channels. The Eastern region, North East and South East all stand out as having a lower level of market concentration than England as a whole (in terms of median $\mathrm{HHI}$, while the marketing of organic produce in the East Midlands is notably more concentrated than the national average.

Some care must be exercised in interpreting these results. Regional averages may obscure considerable intra-regional variation and, as Ilbery et al. (2010) point out, the market strategies of organic farmers are frequently complex and individualised. That said, the differences apparent from Table 1 are likely, in part, to be associated with differences in the regional distribution of farms of different types. As Table 2 indicates, there is a clear association between farm type and the degree of market concentration. It is significant that the mean HHI for dairy farming is 0.88 , reflecting the relatively limited opportunities that these types of farms have for marketing their produce through multiple channels. It is interesting to note that the regions with the lowest HHI score also have the lowest concentration of dairy farms. As could be 
expected, mixed and horticultural holdings, on the other hand, have lower mean and median HHI scores, indicating that produce is sold through more channels. Clearly, other factors such as access to local and affluent markets, the ability to add value, access to processing and distributional infrastructure will also influence regional differences in HHI score. These issues are returned to below.

Table 1 here

Table 2 here

Market orientation: National, regional and local organic marketing strategies ${ }^{6}$

In order to begin to explore the market orientation of organic producers, respondents were asked to indicate the main geographical focus of their organic sales. A total of 431 respondents (i.e. $91 \%$ ) were able to indicate the main focus of their organic sales activities as either local (34.8\%), regional $(28.1 \%)$ or national $(37.1 \%)$. This does not mean that those with a 'local' orientation were exclusively focused on serving the local market as many farmers operate a range of market routes, sometimes supplying both local and regional markets, for instance. As ILBERY et al. (2010) comment, “there is considerable 'blurring' or 'hybridisation' of marketing strategies”. It is, however, a good indication of where the respondent saw their main market. The questionnaire did not define the terms local, regional and national, instead leaving respondents to self define and self select. The justification for this is that as long as a farmer thinks that they are mostly focusing on a particular market (however defined), that will exert an influence on their behaviour and choice of marketing routes. Moreover, as the analysis below indicates, there are some distinct and significant 
differences between the farms and marketing activities of respondents depending on their market orientation.

In terms of the total value of organic sales recorded by the survey, those farms focusing on local markets accounted for $13.7 \%$ of all sales, while those with a regional or national focus accounted for $35.4 \%$ and $50.9 \%$ respectively. Thus, although a local market orientation is important in terms of the number of producers involved, in terms of its contribution to aggregate sales income it is much less significant. This is at least in part due to the smaller size of farm associated with a local market orientation (see below).

Table 3 indicates the geographical distribution of farms with different market orientations. It can be seen that there are some quite notable regional differences. For instance, compared to the sample as a whole, Wales, the North East and the East and West Midlands have a larger share of farms with a largely national market orientation. The North West and Yorkshire and Humberside are characterised by a relatively larger share of business with a regional market focus, whereas the South East, South West and the Eastern region in particular, have a large concentration of producers strongly orientated towards the local market. Comparing Tables 1 and 3, it can be seen that the Eastern region and South East are both characterised by lower than average HHI values and a higher than average proportion of farmers with a local market orientation, indicating that these regions are characterised by organic farms pursuing the local market through a wide variety of market channels. Again, to an extent this can be explained by geographical variations in the distribution of different farm types. Over $31 \%$ of the organic farms in the Eastern region were horticultural 
businesses. None were classified as dairy farms. In the South East it is likely that a combination of farm type, smaller farm size and relatively easy access to large and often relatively affluent local markets encourages an orientation towards the local market. As the analysis below will indicate, however, the market orientation of individual organic farm businesses results from a complex interaction between farm type and size, location and the inclinations, skills and ability of individual farmers.

Table 3 here

By considering the proportion of total sales made through particular market routes, it is apparent that there are some significant differences between marketing strategies depending on where a farmer sees his or her main market. For instance, producers with a 'local' orientation sell $15.6 \%$ of their produce by value through their own box scheme, compared to $4.4 \%$ for those with a regional or national market orientation (See Table 4). Sales through either their own farm shop or other independent local shops are also of greater significance for producers with a local market orientation. On the other hand, locally orientated producers sell a much lower proportion of their produce via a contract with a processor or abattoir compared to those with a regional or national market orientation (the figures being $9.5 \%, 21.2 \%$ and $21.7 \%$ respectively). Marketing co-operatives are also a much less significant route for locally orientated farmers than for those with a regional or national market orientation. This analysis therefore confirms that the overall market focus of a particular business does not imply exclusivity. Locally orientated farms also sell some of their output through regional and national channels but the majority of their sales are made through local marketing routes. The results also point to a greater 
diversity of market routes associated with farmers with a local orientation, whereas for farmers with regional or national market orientations over half of all sales are via marketing co-operatives and contracts with processors. Given that farmers were selfselecting in identifying their overall market orientation, it is interesting to note that the HHI score of those with a local market orientation is significantly lower than for those with a regional or national orientation (see Table 5). This confirms that those targeting local markets are also using a wider range of channels to sell their produce. Farmers with a national market orientation have a significantly higher mean and median HHI, indicating that these farmers are confined to a very few channels, or even a single market channel to sell their produce.

\section{Table 4 here}

Table 5 here

Not only do locally oriented producers have a distinct profile in terms of marketing routes, but these routes are often direct routes to the end consumer, whereas producers with a regional or national focus tend to sell indirectly to the consumer through longer and more complex supply chains: $36.7 \%$ of the value of all produce sold by locally oriented farmers is sold via direct routes $^{7}$ compared to just $7.2 \%$ and $5.2 \%$ respectively for those with a regional or national orientation. The difference between farms with a regional or a national market orientation is less pronounced than between those with a local orientation and all other farmers. Farmers with a regional market orientation tend to sell marginally more to processors and abattoirs, other farmers and packhouses $(22.7 \%, 10.2 \%$ and $4.1 \%$ respectively), compared to nationally focused farms. Sales via marketing co-operatives and by contract with processors are also 
more important for this group compared to those with a local market orientation, but less than those with a national focus. Producers with a national market orientation are different again. Sales through various direct marketing routes are modest, with the majority of sales being made through marketing co-operatives, contracts with processors, and to a lesser extent, wholesalers (farms with a national orientation sell $67.4 \%$ of their output through these three routes compared to $58.9 \%$ in the case of those with a regional focus).

The differences between farmers with different market orientations are not confined to the type of market routes they use. Producers with different market orientations, particularly those with a local orientation, operate a distinct range of enterprises. Compared to those with a regional or national market orientation, they are less likely to operate dairy or cereal enterprises but are much more likely to produce vegetables, salads, fruit, herbs and nuts. In other words, they produce organic food that is arguably easier to add value to through relatively simple packaging and which is easy to market locally. On the other hand, certain enterprises were perceived to be associated with barriers to local and/or direct supply:

Again it is legislation and red tape, I would absolutely love it, to milk in the morning, put it in the back of the pickup and deliver it locally. I would love to do it, but by the time you get the pasteurization in place, it is not impossible, but you would have to be dedicated. You have to do a hell of a lot of marketing. (organic producer, Tanygroes focus group).

Further confirmation of the distinct enterprise profile of organic farms with different market orientations is provided in Table 6, which indicates that farmers with a local market orientation are significantly more likely to operate horticulture farms $(26.7 \%$ 
compared to just $10.1 \%$ of those with a national market focus). This may be at least partially explained by the nature of the produce of horticultural holdings and the relative perishability of that produce. Those with an orientation towards national markets on the other hand are significantly more likely to operate dairy farms $(28.3 \%$ compared to $6.2 \%$ of those with a local orientation). Linked to some extent to the farm type profile of the different groups of farm, farmers pursuing a strategy of local sales are significantly more likely to operate very small farms (under 25 ha) compared to those with a regional or national orientation: $39.3 \%$ of locally orientated farmers operate farms of under 25 ha compared to $7.4 \%$ and $9.4 \%$ respectively of those with a regional or national orientation. Conversely, compared to those focusing on the local market, those with a strong national market orientation are significantly more likely to operate large farms of 200 ha or more. In discussing their market orientation, focus group farmers acknowledged that scale of production was an influence on marketing strategy:

I think it would be very difficult getting rid of the amount of animals we have locally, and because it's just a lot simpler. Vegetables that we produce just go to a vegetarian shop locally. It is basically the simplicity of it; I am busy enough as it is with the work I've got (organic producer, Tanygroes focus group).

Facilitator: What makes you decide whether you are going to focus on supplying a local or national market?

Availability of help I would say, because if you haven't got help you would have very little time to go out to farmers' markets or do any processing, 
adding value on farm. I think that will be the determining factor. Also the scale of the operation. ... As I said the scale of the operation is significant because there's only so much the local (market) will absorb whereas your scale of growing 10 acres of potatoes on the farm then that becomes a national scale because 10 acres cannot be absorbed locally. (Organic producer, Haverfordwest focus group)

As this quote suggests, it is not so much scale per se but the interaction between scale and the size of the local market that can influence decisions about marketing strategies.

Table 6 here

Considering the extent to which the qualities and characteristics of organic produce are emphasised in the sales process reveals further distinctions between farms of different market orientation. As can be seen from Table 7, farmers with a local orientation were significantly more likely to emphasise the 'organicness' of their produce. They were also much more likely to emphasise the freshness of their produce, with $47.6 \%$ citing this as something they emphasise compared to $25.0 \%$ of those with a regional orientation and just $17.9 \%$ of those predominately serving the national market. Of those with a local focus, $39.6 \%$ also emphasise the healthiness of their produce (although we do not know what specific health-related attributes these may be). Therefore, those with a local orientation tend to emphasise a cluster of characteristics (such as localness, freshness, organicness, healthiness and traceability) of the produce they supply whilst, in almost all instances, those with regional or national market orientations are less likely to place emphasis on any of the 
characteristics recorded in the survey. It is notable that $31.7 \%$ of those supplying the national market reported that they did not emphasise any particular quality or characteristic of their produce in their sales compared to only $13.9 \%$ of those with a local market orientation. This suggests that those with a local orientation are making more of an effort to differentiate their produce, both from other local producer/suppliers and from food available locally via national market channels. Indeed, in some instances it seems that the effort involved in direct local marketing, in terms of time and skills required, is encouraging a number of respondents to stick to more established routes with processors, wholesalers and marketing co-operatives with several respondents remarking that:

Do not have the time to market myself (Organic dairy producer, England).

Do not have time for direct marketing (Organic horticultural producer, Wales).

Similarly, a livestock farmer at a focus group reported that:

Our beef and lamb we sell nationally - they tend to go to Tesco's. The factor behind doing it this way was simplicity. So basically from my point of view, anything for a simple life. It is much better to just ring up soand-so and organise a lorry and it's gone (Organic producer, Tanygroes focus group).

Table 7 here

In the following example, although the farmer is attempting to supply organic meat to the local market, he suggests that the local area lacks a sufficiently affluent population to make his approach to marketing viable: 
To supply a local market in this part of the country where you haven't got the affluent people, you cannot do it organically. We do it organically, through our local farm shop, but I must be honest with you, if the organic dead weight price is $£ 3$ per kilo I'm much better off putting it on that lorry and waving it goodbye. ..... It's not worth it; we're taking a loss on it. If we were closer to Cardiff or London it would be a different story (producer, Tanygroes focus group).

In contrast there were also many farmers with very positive attitudes towards direct and local sales. In some cases this was primarily associated with the control it gave to the farmer and improved returns, as well as consumer contact, as the following examples illustrate:

It gives us control over the quality of the produce the local consumer receives, keeps us linked to our customers and gives us the best return for our produce (horticultural producer, England).

By supplying local we can determine our price better. Also by supplying local, we are a well-known farming family in our area, so people know us and that has helped us establish our base. The moment we try to go regional or national we would lose all of that. We would just become a minnow (producer, Brinsbury focus group).

In explaining why they had developed specific local or direct marketing channels other respondents placed greater emphasis on ethical and environmental aspects: Ethically and environmentally the best form of supplying organic fruit and veg (Organic horticultural producer, England). 
Because I believe in taking wholesome food to [the] local community and in humane rearing and slaughter of livestock (Organic cattle and sheep farmer, England).

Farmers involved in direct and local sales frequently valued contact and dialogue with the consumer. As one respondent put it: "It is local and you sell direct to consumers, explaining and getting feedback". Respondents were asked about how they normally receive feedback from their customers. Fewer than $15 \%$ reported that they did not receive feedback from their customers. Of those that do receive feedback, face-toface feedback was most common for those with a local orientation. This is not surprising given that many were involved in sales direct to the end customer and valued the personal interaction that they have with their customers:

I sell vegetables in the Fishguard farmers' market and I get very positive feedback from customers, mostly on taste and on the fact that they (the vegetables) are local (producer, Haverfordwest focus group).

Other forms of personal feedback (mostly via the phone) were equally important to all groups of producers. Those with a national market orientation were more likely than the others to receive feedback via the internet. Presumably this is a reflection of the greater importance of internet sales to this group. Feedback via formal customer surveys was uncommon for all respondents, although slightly less so for those with a local market orientation. A number of other forms of feedback were also recorded by respondents including via abattoir returns, through marketing co-ops and via milk quality analysis. 
When asked what, if any changes had been made in response to customer feedback, one producer simply responded: "Lots. We call it progression at our business". The survey recorded over 60 instances of farmers making changes following feedback from customers. In some cases this was feedback from final consumers and in other cases from intermediaries such as supermarkets. In response to feedback, organic producers had taken steps such as offering customers different cuts of meat, introducing new enterprises, changing packing and presentation of produce, and changing the breed of livestock or other changes to improve livestock quality. For instance, a number of lamb producers who had contracts with Waitrose had taken steps to produce heavier lambs by switching breeds. As one farmer explained: [we] have changed breeds of sheep to obtain more lambs in the right grade. Waitrose don't like "O" grades of lambs or cattle (cattle and sheep farmer, Wales).

Changes to packaging to improve presentation and information were quite common, for instance: "constantly changing products and presentation" and "Labelling organic emphasised now, weight shown". The organic producers in the survey did not always agree with the preferences expressed by their customers, but still made changes as the following example from a horticultural business illustrates:

I have been asked to pack lettuce in plastic bags, which we did as the customer is always right, but I don't agree (horticultural producer, England). 
Some had changed the cuts of meat they offered to better suit customer requirements, with one producer explaining that: "customer feedback on beef steers over recent years lead us to have more steaks and less joints. Lamb shoulders are boned out and breast of lamb is now minced or made into sausages". Other farmers changed the enterprise structure of their business in response to customer feedback: "Customers want organic pork so we started a pig herd. Then they wanted organic bacon so we started to produce our own".

As these examples show, organic farm businesses are responding to customer demand and exploiting new market opportunities. In some cases they are responding to feedback from buyers for major supermarkets and in other cases to the requests of individual, end consumers. Some were clearly responding to the relationship that they had developed with their customers. For instance, one respondent candidly explained that even though he tries to offer all of his customers good quality, it was the local customers who got the best produce: "although we try to produce a uniform good quality product, local people get the best as I meet them often”.

\section{Discussion and conclusions}

Although current organic certification standards do not require organic systems to be based on localised systems of food production and distribution, it is often assumed that organic farming is closely aligned with the relocalisation of food systems (PRETTY et al., 2005). Or it is argued that organic farming should adopt short and direct marketing approaches (LATACZ-LOHMANN and FOSTER 1997). Evidence suggests that this may be more likely in Southern Europe where existing market structures facilitate local and direct sales (DANTSIS et al., 2009; FONTE, 2008). 
Within the UK however, relatively little is known about the marketing strategies of organic farmers. Following the call to challenge assumptions regarding the local nature of organic food chains through more critical accounts of organic supply chains (CLARKE et al., 2008), this paper has sought to contribute to this debate by describing and analysing the marketing strategies and market orientation of organic farmers in England and Wales. Drawing on a mixed methods approach, the survey which forms the basis of most of the empirical content of this paper covered over a fifth of the registered organic farm land in England and Wales. Building on the work of ILBERY et al. (2010) et al., this paper has for the first time calculated indices of marketing concentration of organic farmers across England and Wales. The use of the Herfindahl-Hirschman Index provides an objective and easily replicated measure of marketing concentration. The paper has also explored the marketing strategies and market orientation of organic farmers and in doing so has begun to reveal the uneven geography of organic marketing.

This paper has shown the wide diversity of organic farming situations that exist in England and Wales, but it also demonstrated that production is dominated by a few large producers (in much the same way as the non-organic sector) with the 'top' $10 \%$ of farms in the survey accounting for over half of all sales. There are also many smaller organic producers who, whilst numerically important, contribute a relatively small proportion of total sales. In this sense the survey provides some evidence of the bifurcation of the organic sector in England and Wales highlighted by REED (2009). Subsequent analysis points to a more complex organic sector with some blurring of marketing strategies as identified by ILBERY et al. (2010), although the majority of farmers were able to indicate the main geographical focus of their sales efforts. 
The domestic organic sector is characterised by a wide variety of organic produce sold via an extensive range of market channels. The approach adopted here was to focus on the first destination of organic sales and not necessarily the final consumer. However, it has been shown that while marketing channels where the first destination is represented by an intermediary (such as processor, packhouse, etc) are common, so are more novel, direct and often local routes to the final consumer such as through farmers' markets and box schemes.

Focusing on the supply side characteristics of national, regional and local markets for organic food has revealed a variable geography of organic marketing. For instance, farmers in the South East region have the lowest HHI score indicating the greatest diversity of marketing routes and a large proportion are engaged in serving local markets. This is perhaps not surprising, given that compared to other regions the South East contains the greatest proportion of farms to have diversified into food processing and/or retailing (DEPARTMENT OF ENVIRONMENT, FOOD AND RURAL AFFAIRS, 2009b). However, not one of these differences was statistically significant, indicating that place is less important than suggested by ILBERY et al. (2010). Indeed, although the analysis points to regional differences in both HHI score and farmers' self-declared market orientation, the emerging geography of organic marketing described here results from a complex interaction between farm type and size, locational factors such as proximity to sufficiently large (and possibly) affluent markets, and the skills and inclinations of individual farmers. 
The three distinct market orientations (local, regional and national) identified in the analysis are associated with a different range of organic products, different routes to market, different types of farm and also different types of activity on the farms. Farmers focusing predominately on the local market account for just under $35 \%$ of the sample, but a much smaller $13.7 \%$ of all sales. These results challenge the findings of writers such as SEYFANG (2006) and DANTSIS et al. (2009) who suggest that organic farmers are (and should be) more integrated into their local economies than their non-organic counterparts. The small proportion of aggregate sales accounted for by those with a local market orientation is in part related to the distinct farm size and farm type profile of these businesses, as many operate very small farms. Indeed, some may be the kind of artisanal organic producers catering to local markets identified in debates over conventionalisation (see LOCKIE and HALPIN, 2005). The operators of these farms manage a different and more diverse range of marketing channels, as measured by the HHI score, compared to those with a regional and national market focus. They tend to make more effort to promote specific qualities and attributes of their produce and many clearly valued the relationships developed through reconnecting with customers. In some cases they have adapted aspects of the business in order to respond to customer feedback, even when they did not agree with it! It is perhaps producers of this sort that many consumers have in mind when they purchase organic food and which many commentators have in mind when they draw associations between organic food and socially embedded, economically integrated localised food systems. In this sense they are the 'ideal' or idealised local organic producer. They are perhaps the type of producer DANTSIS et al. (2009) advocate in their normative analysis of organic producers in Macedonia. However, organic certification does not require the development of localised food production and 
distribution systems and in a food economy such as the UK's, dominated by a few multiple retailers, it is perhaps not unexpected that only a minority (albeit a significant minority) of organic producers are orientated towards serving local markets. Although such locally embedded organic producers may benefit from considerable consumer locality (LOBLEY et al., 2009), their longer term future may become increasingly challenging as it has been suggested that a number are struggling to add value and market directly to local end consumers as a result of competition from large scale, multi-regional or even national organic box schemes (ILBERY et al., 2010).

The majority of organic farmers surveyed for this research do not have an orientation to the local market. The reasons for this vary. Some feel that the barriers to local and direct supply are too great, or that they are in locations that lack sufficient population to make a predominantly local marketing strategy viable. This is particularly the case for the operators of larger businesses who often find that they are producing 'too much' for the local market to absorb. They may sell small amounts locally, reflecting a degree of hybridisation and flexibility identified by others (e.g. ILBERY et al., 2010; LOCKIE and HALPIN, 2005) but predominately focus on national markets. Others strongly identified themselves as farmers and producers with neither the time, skills nor the inclination to get involved in direct marketing, often preferring the ease and relative security of selling on contract to processors or via marketing cooperatives. Some producers felt a certain amount of pressure to comply with the new convention of local food for local people even though that was not the way they wanted to configure their business and a number of producers had withdrawn from direct sales activity as it was distracting them from their main business of producing crops and livestock. Rather than see such farms as evidence of creeping 
conventionalisation, perhaps as ROSIN and CAMPBELL (2009) suggest, they should be acknowledged as playing a role in the supply of food produced using alterative production systems and for their contribution to what is a diverse and evolving sector. Indeed, the evidence presented here contributes to the debate over the utility of conventionalisation theory and strengthens the argument that by creating an artificial dualism between the 'good' alternative and 'bad' conventional (ROSIN and CAMPBELL, 2009), conventionalisation fails to give recognition to the diversity of ways of being organic. Moreover, the term 'organic', while broadly useful in terms of distinguishing particular farming systems, is of little use in terms of understanding the configuration and market orientation of a farming business.

This paper has demonstrated the heterogeneity of the organic farming sector in England and Wales. Domestic organic agriculture is characterised by diversity of scale, products and marketing channels. Most organic farmers do not focus largely or even exclusively on their local markets. The majority do not sell to the final consumer but are integrated into longer supply chains though sales to processors and marketing cooperatives. This is not to suggest that local food is unimportant or that more localised food systems do not offer social, environmental and economic benefits but that it cannot be assumed that organic producers are, or should be, closely integrated into the local economy. In turn, this has implications for policy as it challenges the view that organic farming can be used as a vehicle for rural development through the localisation of food systems. The uneven geography of organic marketing strategies means that the local economic impacts of organic farming are geographically specific and are likely to remain so. If it is an objective of policy to support local food it would be unwise to use organic farming as a proxy. Indeed, as WINTER (2003) has argued, 


\section{Acknowledgements}

We are grateful to Defra for funding the research upon which this paper is based. The views expressed here are those of the authors and do not necessarily reflect the views of Defra or other members of the research team. We are grateful to Ika Darnhofer for helpful comments on a earlier draft and to two anonymous referees. 


\section{References}

BEST H. (2008) Organic agriculture and the conventionalization hypothesis: A case study from West Germany, Agriculture and Human Values 25, 95-106.

CLARKE N., CLOKE P., BARNETT C. and MALPASS A. (2008) The spaces and ethics of organic food, Journal of Rural Studies, 24, 219-230.

CRANBROOK C. (2006) The Real Choice: How Local Foods can Survive the Supermarket Onslaught. Campaign to Protect Rural England (CPRE), London.

DANTSIS T., LOUMOU A. and GIOURGA C. (2009) Organic Agriculture's Approach towards Sustainability; Its Relationship with the Agro-Industrial Complex, A Case Study in Central Macedonia, Greece, Journal of Agricultural and Environmental Ethics, 22, 197-216.

DARNHOFER I. (2005) Organic Farming and Rural Development: Some Evidence from Austria, Sociologia Ruralis, 45, 308-323.

DARNHOFER I., LINDENTHAL T., BARTEL-KRATOCHVIL R. and ZOLLITSCH W. (2010) Conventionalisation of organic farming practices: from structural criteria towards an assessment based on organic principles. A review. Agronomy for Sustainable Development 30, 67-81. 
DEPARTMENT FOR ENVIRONMENT, FOOD AND RURAL AFFAIRS (DEFRA) (2009a) Organic Statistics 2008. Department for Environment, Food and Rural Affairs, York.

DEPARTMENT FOR ENVIRONMENT, FOOD AND RURAL AFFAIRS (DEFRA) (2009b) Farm Diversification in England: Results from the Farm Business Survey, 2007/08. Department for Environment, Food and Rural Affairs, London.

FONTE M. (2009) Knowledge, food and place. A way of producing, a way of knowing, Sociologia Ruralis 48, 200-222.

GABRIEL D., CARVER S. J., DURHAM H., KUNIN W. E., PALMER R. C., SAIT S. M., STAGL S. and BENTON T. G. (2009) The spatial aggregation of organic farming in England and its underlying environmental correlates, Journal of Applied Ecology 46, 323-333.

GUPTILL A. (2009) Exploring the conventionalization of organic dairy: trends and counter-trends in upstate New York, Agriculture and Human Values 26, 29-42.

GUTHMAN J. (2004) Back to the land: the paradox of organic food standards, Environment and Planning A 36, 511-528.

HALL A. and MOGYORODY V. (2001) Organic farmers in Ontario: an examination of the conventionalisation argument, Sociologia Ruralis 41, 399-422. 
HERFINDAHL O. C. (1950) Concentration in the U.S. Steel Industry. Ph.D. thesis, Columbia University, New York.

HIRD V. (1997) Double Yield: Jobs and Sustainable Food Production. SAFE Alliance, London.

HIRSCHMAN A. O. (1964) The paternity of an index, American Economic Review $54,761-762$.

ILBERY B. and MAYE D. (2005) Alternative (shorter) food supply chains and specialist livestock products in the Scottish-English borders, Environment and Planning A 37, 823-844.

ILBERY B. and MAYE D. (2010) Clustering and the spatial distribution of organic farming in England and Wales, Area DOI: 10.1111/j.1475-4762.2010.00953.x.

ILBERY B., COURTNEY P., KIRWAN J. and MAYE D. (2010) Marketing

concentration and geographical dispersion: a survey of organic farms in England and Wales, British Food Journal, 112 (9) 962-975

ILBERY B., WATTS S., SIMPSON S., GILG A., and LITTLE J. (2006) Mapping local food: evidence from two English regions, British Food Journal, 108 (3) 213-225 
ILBERY B., HOLLOWAY L. and ARBER R. (1999) The geography of organic farming in England and Wales in the 1990s. Tijdschrift voor Economische en Sociale Geografie 90, 285-295

LATACZ-LOHMANN U. and FOSTER C. (1997) From “niche” to “mainstream” strategies for marketing organic food in Germany and the UK, British Food Journal, $99,275-282$.

LEE J.-Y. and BROWN M. G. (1989) Consumer demand for food diversity. Southern Journal of Agricultural Economics 21, 47-53.

LOBLEY M., BUTLER A. and REED M. (2009) The contribution of organic farming to rural development: an exploration of the socio-economic linkages of organic and non-organic farms in England, Land Use Policy 26, 723-735.

LOBLEY M., REED M. and BUTLER A. (2005) The Impact of Organic Farming on the Rural Economy, Centre for Rural Research (CRR) Report No 11, University of Exeter, Exeter.

LOCKIE S. and HALPIN D. (2005) The 'conventionalisation' thesis reconsidered: structural and ideological transformation of Australian agriculture, Sociologia Ruralis 45, 284-307. 
MICHÈLE E. and MICHAEL D. (2009) Effects of agri-environment schemes in a long-term ecological time series, Agriculture, Ecosystems and Environment 130, 915.

MIDMORE P. and LAMPKIN N. (1994) Modelling the impact of widespread conversion to organic farming: an overview, in LAMPKIN, N. and PADEL, S. (eds.) The Economics of Organic Farming: an International Perspective. CABI International, Wallingford.

MILLER R. A, (1982) The Herfindahl-Hirschman Index as a market structure variable: an exposition for antitrust practitioners, The Antitrust Bulletin 27, 593-618.

MORISON J., HINE R., and PRETTY J. (2005) Survey and analysis of labour on organic farms in the UK and Republic of Ireland, International Journal of Agricultural Sustainability 3, 24-43.

PADEL S. and LAMPKIN N. (1994) Conversion to organic farming: an overview, in LAMPKIN N. and PADEL S. (eds.) The Economics of Organic Farming: An International Perspective. CABI International, Wallingford.

PADEL S., RÖCHLINSBERG H. and SCHMID O. (2009) The implementation of organic principles and values in the European Regulation for organic food, Food Policy 34, 245-251. 
PRETTY J., BALL A., LANG T. and MORISON J. (2005) Farm costs and food miles: an assessment of the full cost of the UK weekly food basket, Food Policy 30, 1-19.

REED M. (2009) For whom? - The governance of organic food and farming in the UK, Food Policy 34, 280-286.

ROSIN C. and CAMPBELL H. (2009) Beyond bifurcation: examining the conventions of organic agriculture in New Zealand, Journal of Rural Studies 25, 3547.

RUNDLOF M., BENGTSSON J. and SMITH H. (2008) Local and landscape effects of organic farming on butterfly species richness and abundance, Journal of Applied Ecology 45, 813-820.

SEYFANG G. (2006) Ecological citizenship and sustainable consumption: examining local organic food networks, Journal of Rural Studies, 22, 383-395.

SEYFANG G. (2007) Cultivating carrots and community: local organic food and sustainable consumption, Environmental Values 16, 105-123. 
SMITH E. and MARSDEN T. (2004) Exploring the 'limits to growth' in UK organics: beyond the statistical image, Journal of Rural Studies 20, 345-357.

SOIL ASSOCIATION (2001) Organic food and farming 2001. Soil Association Bristol.

SOIL ASSOCIATION (2007) Organics Market Report 2007. Soil Association, Bristol.

SOIL ASSOCIATION (2009) Organics Market Report 2009. Soil Association, Bristol.

STOLZE M. and LAMPKIN N. (2009) Policy for organic farming: rationale and concepts, Food Policy 34, 237-244.

TOMLINSON I. (2008) Re-thinking the transformation of organics: The role of the UK government in shaping British organic food and farming, Sociologia Ruralis 48, $133-151$.

TOVEY H. (1997) Food, environmentalism and rural sociology: on the organic farming movement in Ireland, Sociologia Ruralis 37, 21-37. 
1

3

4

5

6

7

8

9

10

11

12

13

14

15

16

17

18

19

20

21

22

23

24

25

26

27

28

29

30

31

32

33

34

35

36

37

38

39

40

41

42

43

44

45

46

47

48

49

50

51

52

53

54

55

56

57

58

59

60

WILLER H. and KLICHER L. (Eds.) (2009) The World of Organic Agriculture. Statistics and Emerging Trends 2009. International Federation of Organic Agricultural Movements (IfOM), Bonn; Forschungsinstitut für biologischen Landbau (FiBL), Frick; International Trade Centre (ITC), Geneva.

WINTER, M. (2003) Embeddedness, the new food economy and defensive localism, Journal of Rural Studies 19, 23-32. 
Table 1: Marketing concentration (HHI score) in England and Wales

\begin{tabular}{lll}
\hline Region/Country & Mean HHI & Median HHI \\
& score & score \\
\hline East Midlands & 0.80 & 0.90 \\
Eastern & 0.69 & 0.75 \\
North East & 0.78 & 0.76 \\
North West & 0.76 & 0.82 \\
South East & 0.70 & 0.71 \\
South West & 0.77 & 0.82 \\
West Midlands & 0.79 & 0.82 \\
Yorkshire/Humberside & 0.73 & 0.82 \\
\hline England & 0.75 & 0.82 \\
Wales & 0.73 & 0.75 \\
England \& Wales & 0.75 & 0.82 \\
\hline
\end{tabular}

${ }^{\mp}$ Using one way ANOVA test, HHI mean scores for each region are not significantly different. 
Table 2: Marketing concentration (HHI score) of different farm types

\begin{tabular}{lll}
\hline Region/Country & \multicolumn{1}{c}{$\begin{array}{l}\text { Mean HHI } \\
\text { score }^{* * *}\end{array}$} & score \\
\hline Dairy & 0.88 & 0.96 \\
Cattle \& Sheep & 0.73 & 0.69 \\
Arable & 0.82 & 1.00 \\
Mixed & 0.66 & 0.66 \\
Horticulture & 0.71 & 0.74 \\
Other & 0.89 & 1.00 \\
\hline All farm types & 0.75 & 0.82 \\
\hline **** & & \\
\hline
\end{tabular}

${ }^{\text {**** }}$ Using one way ANOVA test, HHI mean scores for each farm type are significantly different when $\mathrm{P}<0.001$. 
Table 3: Regional differences in farmers’ main market orientation ${ }^{\ddagger}$

\begin{tabular}{lccc}
\hline Region/Country & Local \% & Regional \% & National \% \\
\hline East Midlands & 18.2 & 30.3 & 51.5 \\
Eastern & 48.1 & 18.5 & 33.3 \\
North East & 33.3 & 8.3 & 58.3 \\
North West & 29.4 & 35.3 & 35.3 \\
South East & 40.4 & 25.5 & 34.0 \\
South West & 39.7 & 32.2 & 28.1 \\
West Midlands & 23.8 & 31.0 & 45.2 \\
Yorkshire/Humberside & 36.0 & 36.0 & 28.0 \\
\hline England & 35.3 & 29.6 & 35.1 \\
Wales & 32.1 & 22.2 & 45.7 \\
\hline ificant association exists between regions and main market orientation.
\end{tabular}

${ }^{*}$ No significant association exists between regions and main market orientation. 
Table 4: The association between main market orientation and the proportion of sales via different marketing routes

\begin{tabular}{|c|c|c|c|}
\hline & Local & Regional & National \\
\hline & \multicolumn{3}{|c|}{$\%$ of sales by value } \\
\hline Own box scheme (Meat) ${ }^{*}$ & 5.0 & 1.3 & 1.3 \\
\hline Own box scheme $(\mathrm{Veg})^{* * *}$ & 10.9 & 1.5 & 0.5 \\
\hline Farmers' market ${ }^{* * *}$ & 9.2 & 2.5 & 1.4 \\
\hline Internet sales & 0.4 & 0.0 & 1.6 \\
\hline Own farm shop ${ }^{* * *}$ & 8.8 & 1.8 & 0.3 \\
\hline Farm-gate $^{*}$ & 2.5 & 0.1 & 0.0 \\
\hline Restaurants and private caterer & 2.5 & 1.1 & 1.1 \\
\hline Local privately owned shop ${ }^{* * *}$ & 7.3 & 2.1 & 0.6 \\
\hline Co-op/company box scheme & 2.3 & 1.9 & 1.6 \\
\hline Direct to another farmer ${ }^{*}$ & 13.3 & 10.2 & 6.4 \\
\hline Public sector caterer & 0.3 & 0.0 & 0.0 \\
\hline Contract with supermarket & 2.8 & 6.1 & 8.2 \\
\hline Contract with processor/abattoir ${ }^{* *}$ & 9.6 & 22.7 & 22.1 \\
\hline Pack house & 1.0 & 4.1 & 2.4 \\
\hline Livestock market & 4.9 & 4.2 & 4.0 \\
\hline Grain Merchant & 0.2 & 2.4 & 2.1 \\
\hline Marketing co-operative ${ }^{* * *}$ & 11.1 & 29.1 & 34.5 \\
\hline Wholesale & 6.3 & 7.1 & 10.9 \\
\hline Other & 1.7 & 1.4 & 0.8 \\
\hline
\end{tabular}


$\begin{array}{llll}\text { Total } & 100.0 & 100.0 & 100.0\end{array}$

Using one way ANOVA test, mean scores for each farm marketing route are significantly different when $* \mathrm{P}<0.001, * * \mathrm{P}<0.01$ and $* \mathrm{P}<0.05$ 
Table 5: The association between main market orientation and market concentration (HHI score)

\begin{tabular}{|c|c|c|}
\hline Main market orientation & Mean HHI score ${ }^{* * *}$ & Median HHI score \\
\hline Local & 0.69 & 0.66 \\
\hline Regional & 0.76 & 0.82 \\
\hline National & 0.81 & 0.91 \\
\hline All farms & 0.75 & 0.82 \\
\hline
\end{tabular}


Table 6: The association between main market orientation and farm type **** $^{\text {* }}$

\begin{tabular}{|c|c|c|c|c|}
\hline \multirow[b]{2}{*}{ Farm Type } & \multicolumn{4}{|c|}{ Main market orientation } \\
\hline & Local \% & Regional \% & National \% & All farms $\%$ \\
\hline Dairy & 6.2 & 23.5 & 28.3 & 19.3 \\
\hline Cattle \& Sheep & 37.0 & 31.9 & 23.3 & 30.4 \\
\hline Arable & 4.1 & 5.9 & 5.0 & 5.0 \\
\hline Mixed & 24.0 & 28.6 & 25.8 & 25.9 \\
\hline Horticulture & 26.7 & 6.7 & 10.1 & 14.9 \\
\hline Other & 2.1 & 3.4 & 7.5 & 4.5 \\
\hline All farm types & $100.0 \%$ & $100.0 \%$ & $100.0 \%$ & $100.0 \%$ \\
\hline
\end{tabular}


Table 7: The association between market orientation and the characteristics of produce emphasised during sales

\begin{tabular}{lccc}
\hline Emphasis & Local \% & Regional \% & National \% \\
\hline Organicness ${ }^{*}$ & 85.5 & 67.5 & 75.8 \\
Local food $^{* * *}$ & 76.6 & 46.3 & 26.3 \\
Regional provenance & 16.1 & 23.8 & 20.0 \\
Free range & 25.8 & 20.0 & 22.1 \\
Traditional breeds & 36.3 & 26.3 & 37.9 \\
Freshness & \\
Traceability & 47.6 & 25.0 & 17.9 \\
Healthy food & 46.8 & 52.5 & 52.6 \\
Other emphasis & 36.3 & 15.0 & 26.3 \\
\hline P & 17.7 & 12.5 & 12.6 \\
market orientation and character of produce emphasized when selling.
\end{tabular}

\footnotetext{
${ }^{1}$ At least some of this increase reflects improvements in data recording.

${ }^{2}$ The Soil Association in an independent charity founded in 1946 and is regarded as the UK's leading organic organisation. In addition to promoting organic food through educational campaigns and community programmes, its subsidiary company, Soil Association Certification Ltd, awards organic certification to farms and business meeting Soil Association organic standards. It is the largest organic certification body in the UK.
} 
${ }^{3}$ In adopting this approach sub regions of Wales have not been identified. The presentation of figures for the whole of Wales alongside the English regions reflects the manner in which national statistics are presented. In addition, in terms of the sensitivity of the LQ methodology to smaller geographical units, Wales is similar in terms of geographic size to the English GORs. It has the second largest area after the South West of England and is only marginally larger than the Eastern and South East regions of England.

${ }^{4}$ The median size of farms was lower at 92 ha. On average $82.9 \%$ of the area of each survey farm was registered as organic (excluding land in conversion). A few farms (7\%) had all land still in conversion, while $60.3 \%$ had all land in registered organic production.

${ }^{5}$ We are grateful to Brian Ilbery for introducing us to this approach.

${ }^{6}$ It is important to note here that the research was concerned with the relative location (local, regional, national) of marketing activities and as such contributes to debates over local food (i.e. food produced and marketed in a defined 'local' area). In this sense, 'local' food is distinct from 'locality' food. The latter is usually considered to be food that is produced and processed in a particular place but which is distributed much more widely (ILBERY et al., 2006).

${ }^{7}$ Direct routes are defined here as those that directly serve the end consumer with no intermediary stages, such as sales via own box scheme, at a farmers' market, farm gate sales, own farm shop sales or direct to consumers from internet sales. 